\title{
RELATIONSHIPS OF KNOWLEDGE TOWARD GLAUCOMA AND QUALITY OF LIFE OF GLAUCOMA PATIENTS IN JEMBER HOSPITAL, EAST JAVA
}

\author{
Reza Ramadhana Tahta Firmansyah \\ Masters Program in Public Health, Universitas Sebelas Maret
}

\begin{abstract}
Background: Glaucoma is a non - communicable, chronic eye disease which needs the principles of long-term care. The asymptomatic nature along with the irreversible blindness it causes makes glaucoma a public health challenge and the second cause of avoidable blindness globally. Glaucoma blindness imposes significant economic burden, increases healthcare cost, impairs quality of life, and increases rehabilitation cost for the blind. Public awareness and knowledge of glaucoma plays a significant role in raising public health seeking behavior for regular eye check and increases the chance of identifying undetected cases. This study aimed to examine relationships of knowledge toward glaucoma and quality of life of glaucoma patients.

Subjects and Method: A cross sectional study was carried out at Baladhika Husada Hospital, Jember, East Java, Indonesia, from January to February 2020. A sample of 71 glaucoma patients was selected by purposive sampling. The dependent variable was quality of life. The independent variable was knowledge. Quality of life was measured by the Glaucoma Quality of Life-15 (GQL-15). Other variables were measured by questionnaire. The data were analyzed by a simple linier regression.

Results: Good knowledge on glaucoma improved quality of life in glaucoma patients (b=0.60; 95\% $\mathrm{CI}=0.51$ to $0.69 ; \mathrm{p}<0.001$ ).

Conclusion: Good knowledge on glaucoma improves quality of life in glaucoma patients.
\end{abstract}

Keywords: glaucoma, knowledge, quality of life

\section{Correspondence:}

Reza Ramadhana Tahta Firmansyah. Masters Program in Public Health, Universitas Sebelas Maret. Jl. Ir. Sutami 36A, Surakarta 57126, Central Java, Indonesia. Email: ramadhanatahta@gmail.com. Mobile: 082228390930. 